\title{
Multifocal Langerhans Cell Histiocytosis: A Unique Presentation of Eosinophilic Granuloma with Intracranial Extension, Massive Lymphadenopathy, and Epstein-Barr Viral Infection in an Adolescent Female
}

\author{
Kent Wade Foster ${ }^{a}$ Shamika Kayo Robinson ${ }^{b} \quad$ Eleanor Tung-Hahn ${ }^{c}$ \\ George Gibbons $^{d}$ Carl Wayne Cruse ${ }^{e} \quad$ Kumaran Mudaliar $^{f}$ \\ Rebecca Tung ${ }^{g}$ Wendy Kim ${ }^{b}$ \\ aDepartment of Biology, Brigham Young University, Provo, UT, USA; b Division of \\ Dermatology, Loyola University Chicago Stritch School of Medicine, Maywood, IL, USA; \\ 'Department of Public Health, The University of South Florida, Tampa, FL, USA; ${ }^{d}$ Dermpath \\ Diagnostics, Tampa, FL, USA; ${ }^{e}$ Cutaneous Oncology Program, Moffitt Cancer Center,

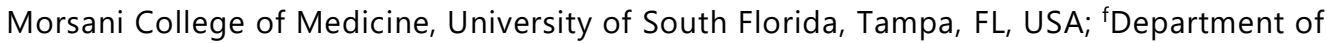 \\ Pathology, Loyola University Chicago Stritch School of Medicine, Maywood, IL, USA; \\ gFlorida Dermatology and Skin Cancer Centers, Winter Haven, FL, USA
}

\section{Keywords}

Multifocal Langerhans cell histiocytosis · Eosinophilic granuloma · Intracranial extension · Lymphadenopathy · Epstein-Barr virus

\begin{abstract}
We report the case of an otherwise healthy 17-year-old female who presented for surgical removal of an enlarging "atypical cyst" on her scalp. During subtotal excision, only friable serosanguinous translucent ribbons of tissue were found. A histopathologic diagnosis of Langerhans cell histiocytosis (LCH) was rendered and imaging studies revealed extradural invasion of the tumor. Within weeks, the patient also developed progressive lymphadenopathy with
\end{abstract}

$\begin{array}{ll} & \text { Shamika Kayo Robinson } \\ & \text { Division of Dermatology, Loyola University Chicago } \\ & 321 \mathrm{~N} . \text { La Grange Road } \\ \text { La Grange Park, IL } 60526 \text { (USA) } \\ \text { srobinson15@luc.edu }\end{array}$




\section{Case Reports in Dermatology}

Case Rep Dermatol 2021;13:28-35

DOI: $10.1159 / 000511488$

(c) 2021 The Author(s). Published by S. Karger AG, Basel www.karger.com/cde

Foster et al.: Multifocal LCH with Intracranial Extension, Lymphadenopathy, and EBV Infection

grossly elevated levels of Epstein-Barr virus viral capsid antigen antibody levels. This report aims to highlight a unique presentation of $\mathrm{LCH}$ with discussion of workup, management, and avoidance of potential surgical complications.

(C) 2021 The Author(s)

Published by S. Karger AG, Basel

\section{Introduction}

Langerhans cell histiocytosis (LCH) is a rare clonal proliferative disorder of epidermal dendritic cells with a wide range of clinical manifestations. The pathogenesis of LCH is incompletely understood. Some studies posit a viral or immunologic origin. BRAF mutants are also a frequent occurrence $[1,2]$. It has been reported that approximately $57 \%$ of reviewed LCH cases displayed this mutation $[1,3]$. The most common clinical presentation of LCH are bony lesions. The skin is the second most commonly affected organ $[1,4,5]$. Dissemination to other organs is less frequently seen; however, a comprehensive history, thorough physical examination, and appropriate workup should be undertaken. When atypical subcutaneous lesions on the head are encountered, the dermatologist's approach must be cautious, and conditions such as LCH, which can extend intracranially, must be considered.

In this report, we describe an unusual case of multifocal LCH with intracranial extension, massive lymphadenopathy, and Epstein-Barr virus (EBV) infection in an adolescent female and review the current diagnostic workup and treatment options.

\section{Case Report}

An otherwise healthy 17-year-old female (Fitzpatrick skin type I) presented with a 1-month history of an enlarging nodule on the right frontal scalp. Prior to this point, her pediatrician prescribed her oral antibiotics (cephalexin) which resulted in no improvement. She was referred to dermatology for excision. The patient had no prior history of trauma, weight loss, fevers, chills, visual symptoms, headaches, polydipsia, polyuria, or other constitutional symptoms. Furthermore, there was no personal or family history of seizures, hemangiomas, neurofibromatosis, or other neurocutaneous disorders.

Physical examination revealed a young woman with no neurologic deficits. A $4 \times 4 \mathrm{~cm}$ soft, semimobile, nontender subcutaneous mass on the right frontal scalp was identified (Fig. 1). No lymphadenopathy was palpated. Administration of local anesthesia with $0.5 \%$ lidocaine with 1:200,000 epinephrine and sodium bicarbonate was uneventful. During subtotal excision, the lesion was explored only to the layer of the deep dermis due to atypical findings. No cystic structures were identified. Instead, friable serosanguinous translucent ribbons of tissue and gelatinous material were encountered. Due to the unexpected features of the lesion, complete excision was forgone and only a partial specimen was removed.

Histopathologic analysis demonstrated proliferation of dendritic cells with mitotic figures, widespread tissue necrosis, eosinophils, lymphocytes, histiocytes, and large osteoclastlike giant cells (Fig. 2, 3). Immunohistochemistry staining was positive for vimentin, S100 (Fig. 4), CD1a (Fig. 5), CD68, and CD207 (langerin), confirming a diagnosis of LCH. Testing of the tissue for BRAF mutant assay for the V600E variant and in situ hybridization for EBV DNA were negative.

\section{Karger'=}




\section{Case Reports in Dermatology}

Case Rep Dermatol 2021;13:28-35

DOI: $10.1159 / 000511488$

(c) 2021 The Author(s). Published by S. Karger AG, Basel www.karger.com/cde

Foster et al.: Multifocal LCH with Intracranial Extension, Lymphadenopathy, and EBV Infection

Within 2 weeks, the patient reported new painful lymphadenopathy on her right neck (Fig. 6). She was referred to hematology-oncology for evaluation. Imaging studies (CT scan, MRI, PET scan) revealed tumor extension from the scalp through the calvarium with extradural invasion (Fig. 7); prominent lymphadenopathy was seen within the supraclavicular and cervical chains as well as palatine tonsillar enlargement. Chest X-ray and skeletal survey (noncranial) were normal.

Screening laboratory testing was obtained to exclude other organ system involvement. Complete blood count with differential was normal except for slight iron deficiency anemia (hemoglobin $10.9 \mathrm{~g} / \mathrm{dL}$, hematocrit $33.7 \%$, ferritin $8 \mathrm{ng} / \mathrm{mL}$ ) and mild reactive thrombocytosis (platelet 495,000/ $\mu \mathrm{L}$ ). Comprehensive metabolic profile and urinalysis were normal, ruling out diabetes insipidus. Lactate dehydrogenase, C-reactive protein, erythrocyte sedimentation rate, and coagulation studies were also normal. Vitamin D levels were normal. After consulting with oncology, the patient and her family initially opted for clinical monitoring.

Serology studies were also ordered, and grossly elevated levels of EBV viral capsid antigen (VCA) antibody (IgG) levels $(306.00 \mathrm{U} / \mathrm{mL})$ were noted. She was started on empiric antiviral therapy (ganciclovir $450 \mathrm{mg}$ orally twice daily for 8 weeks). Her lymphadenopathy and the cutaneous aspect of her scalp lesion resolved. At 2 months, the patient requested further surgical evaluation because she perceived that the lesion was "going deeper" due to the focal deficit of the calvarium. As an active teenager, she was also uncomfortable with the recommendation to refrain from participation in contact sports. To address her concerns, she was referred to neurosurgery. Cranioplasty was later performed to restore the cranial contour, which resulted in improved patient satisfaction.

\section{Discussion}

The incidence of LCH is estimated to be about 2-10 cases in 100,000 per year [6]. The majority of cases occur in young children [1]. In dermatology, any indication that a subcutaneous scalp lesion might extend more deeply should raise concern and prompt a cautious diagnostic and therapeutic approach. The skeletal system is most commonly affected in LCH [1, $4,5,7]$. In our patient, her initial benign clinical presentation of LCH gave no indication of the underlying calvarium erosion. Had a full-on excision been performed in this case, penetration of the dura and deeper structures could have resulted. Responding to intraoperative clues allowed us to modify our course of action and avoid a potentially very adverse event. Additionally, the prescribed oral antibiotics (doxycycline hyclate $120 \mathrm{mg}$ daily for 4 weeks) may have helped to prevent infection and inflammation.

Since testing for the BRAF mutant assay for V600E variant yielded a negative result, treatment with BRAF or mitogen-activating protein kinase inhibitors was not indicated. Some studies $[8,9]$ have indicated that EBV may be a causative agent in some cases of LCH. While in situ hybridization testing for EBV viral DNA performed on her cutaneous specimen was negative, her serology revealed elevated levels of VCA IgG levels. Given these data and her evolving clinical presentation, we started the patient on a course of ganciclovir. Fang et al. [8] previously described a case of LCH and EBV in a 1-year-old male who presented with prolonged fever, cervical and abdominal lymphadenopathy, hepatosplenomegaly, pneumonia, and anemia [8]. EBV was initially confirmed through elevated IgM antibody titer and later with VCA IgG positivity. This patient was treated intravenously with ceftriaxone, ganciclovir, and immunoglobulin. While this patient's multifocal LCH did not resolve, it was postulated that active EBV

\section{Karger'=}




\section{Case Reports in Dermatology}

Case Rep Dermatol 2021;13:28-35

DOI: $10.1159 / 000511488$

(c) 2021 The Author(s). Published by S. Karger AG, Basel www.karger.com/cde

Foster et al.: Multifocal LCH with Intracranial Extension, Lymphadenopathy, and EBV Infection

infection played a causative role in the development of his LCH. Shimakage et al. [9] described a 1-year-old male who developed a skull tumor. CT scan revealed the presence of an osteolytic lesion with intradural extension. Biopsy confirmed a diagnosis of LCH and EBV was detected on mRNA in situ hybridization. Successful remission of this boy's LCH followed treatment with intravenous acyclovir. These reports and ours suggest a possible role of antiviral therapy in confirmed cases of EBV with LCH. Other treatment options available for $\mathrm{LCH}$, based on disease involvement and patient preference, include chemotherapy, surgery, radiation therapy, phototherapy, immunotherapy, targeted therapy, other medications (examples include retinoids and anti-inflammatory medications), stem cell transplantation, and close clinical monitoring $[2,7,10-13]$.

Histopathology and immunohistochemical techniques are commonly used to confirm the diagnosis of $\mathrm{LCH}$, with langerin (CD207) being the key diagnostic stain $[2,4,5]$. Positive staining for CD1a and S100 is also seen [4,8]. Electron microscopy can be used to identify Birbeck granules, a langerin-based organelle unique to Langerhans cells [5]. Upon immunohistochemical and microscopic diagnosis of LCH, distant organ involvement can be assessed by detailed history and physical examination, laboratory testing, and imaging studies [2, 4-6, 14, 15]. Query regarding constitutional symptoms and review of all systems is essential. When conducting the physical examination, it is imperative to palpate for lymphadenopathy, identify any cutaneous lesions, and assess for liver, spleen, and bone involvement. Laboratory testing and workup include, but are not limited to, a complete blood count, coagulation studies, complete metabolic profile including liver enzymes, endocrine studies, and urinalysis [6]. Imaging studies such as an abdominal ultrasound, chest radiograph, whole-body CT scan, and head MRI can assess the extent of disease involvement in the hepatic, hematopoietic (spleen), pulmonary, lymphatic, endocrine (thyroid), osseous, and the central nervous systems $[2,4,5]$. Assessment of BRAF mutant assay for V600E variant status within the affected tissue as well as testing for EBV infection may also be of value. Given the rare nature and the myriad of clinical manifestations of LCH, it is still typically a diagnosis of exclusion. This case serves as a reminder that particular care and attention should be taken when approaching atypical scalp lesions, as this and other types of growths may penetrate through bone and deeper structures. As in all procedures, it is vital for the physician and medical team to react appropriately to intraoperative feedback so that optimal outcomes may be attained.

Encountering an atypical scalp lesion warrants careful acquisition of tissue for histopathologic analysis. If LCH is diagnosed, extensive workup and collaboration with hematologyoncology for complete staging and management is recommended.

\section{Acknowledgment}

Our thanks go to Jessica Wishnew, MD for her advice and guidance on therapy.

\section{Statement of Ethics}

This study complies with the guidelines for human studies and was conducted ethically in accordance with the World Medical Association Declaration of Helsinki. The parents/guardians gave their written informed consent for publication of this case, including publication of images.

\section{Karger'=}




\section{Case Reports in Dermatology}

\begin{tabular}{l|l}
\hline Case Rep Dermatol 2021;13:28-35 \\
\hline DOI: 10.1159/000511488 & $\begin{array}{l}\text { @ 2021 The Author(s). Published by S. Karger AG, Basel } \\
\text { www.karger.com/cde }\end{array}$ \\
\hline
\end{tabular}

Foster et al.: Multifocal LCH with Intracranial Extension, Lymphadenopathy, and EBV Infection

\section{Conflict of Interest Statement}

The authors have no conflicts of interest to declare.

\section{Funding Sources}

The authors received no specific funding for this work.

\section{Author Contributions}

K.W. Foster contributed as the primary author of the manuscript and to data gathering. S.K. Robinson, BS contributed to manuscript writing and data gathering. E. Tung-Hahn contributed to manuscript writing and data gathering. G. Gibbons, MD contributed to manuscript data gathering and review. C.W. Cruse, MD contributed to manuscript data gathering and review. K. Mudaliar, MD contributed to manuscript data gathering and review. R. Tung, MD contributed to manuscript data gathering, writing, and review. W. Kim, DO contributed to manuscript data gathering, writing, and review.

\section{References}

1 Krooks J, Minkov M, Weatherall AG. Langerhans cell histiocytosis in children: History, classification, pathobiology, clinical manifestations, and prognosis. J Am Acad Dermatol. 2018 Jun;78(6):1035-44.

2 Krooks J, Minkov M, Weatherall AG. Langerhans cell histiocytosis in children: Diagnosis, differential diagnosis, treatment, sequelae, and standardized follow-up. J Am Acad Dermatol. 2018 Jun;78(6):1047-56.

3 Badalian-Very G, Vergilio JA, Degar BA, MacConaill LE, Brandner B, Calicchio ML, et al. Recurrent BRAF mutations in Langerhans cell histiocytosis. Blood. 2010 Sep;116(11):1919-23.

4 Howarth DM, Gilchrist GS, Mullan BP, Wiseman GA, Edmonson JH, Schomberg PJ. Langerhans cell histiocytosis: diagnosis, natural history, management, and outcome. Cancer. 1999 May;85(10):2278-90.

5 Haupt R, Minkov M, Astigarraga I, Schäfer E, Nanduri V, Jubran R, et al.; Euro Histio Network. Langerhans cell histiocytosis (LCH): guidelines for diagnosis, clinical work-up, and treatment for patients till the age of 18 years. Pediatr Blood Cancer. 2013 Feb;60(2):175-84.

6 PDQ® Pediatric Treatment Editorial Board. Langerhans Cell Histiocytosis Treatment (PDQ®) - Health Professional Version (updated June 13, 2019). Bethesda, MD: National Cancer Institute. Available at: www.cancer.gov/types/langerhans/hp/langerhans-treatment-pdq [accessed November 13, 2019].

7 Lindahl LM, Fenger-Grøn M, Iversen L. Topical nitrogen mustard therapy in patients with Langerhans cell histiocytosis. Br J Dermatol. 2012 Mar;166(3):642-5.

8 Fang YH, Lou JG, Zhao H, Chen J. Association of Langerhans Cell Histiocytosis with Chronic Active EpsteinBarr Virus Infection: Case Report and Review of the Literature. Hong Kong J Paediatr. 2015;20:252-5.

9 Shimakage M, Sasagawa T, Kimura M, Shimakage T, Seto S, Kodama K, et al. Expression of Epstein-Barr virus in Langerhans' cell histiocytosis. Hum Pathol. 2004 Jul;35(7):862-8.

10 Kudo K, Ohga S, Morimoto A, Ishida Y, Suzuki N, Hasegawa D, et al. Improved outcome of refractory Langerhans cell histiocytosis in children with hematopoietic stem cell transplantation in Japan. Bone Marrow Transplant. 2010 May;45(5):901-6.

11 Zinn DJ, Grimes AB, Lin H, Eckstein O, Allen CE, McClain KL. Hydroxyurea: a new old therapy for Langerhans cell histiocytosis. Blood. 2016 Nov;128(20):2462-5.

12 Simko SJ, McClain KL, Allen CE. Up-front therapy for LCH: is it time to test an alternative to vinblastine/ prednisone? Br J Haematol. 2015 Apr;169(2):299-301.

13 Büchler T, Cervinek L, Belohlavek O, Kantorova I, Mechl M, Nebesky T, et al. Langerhans cell histiocytosis with central nervous system involvement: follow-up by FDG-PET during treatment with cladribine. Pediatr Blood Cancer. 2005 Mar;44(3):286-8. 


\section{Case Reports in Dermatology}

\begin{tabular}{l|l}
\hline Case Rep Dermatol 2021;13:28-35 \\
\hline DOI: 10.1159/000511488 & $\begin{array}{l}\text { C } 2021 \text { The Author(s). Published by S. Karger AG, Basel } \\
\text { www.karger.com/cde }\end{array}$ \\
\hline
\end{tabular}

Foster et al:: Multifocal LCH with Intracranial Extension, Lymphadenopathy, and EBV Infection

14 Grois N, Pötschger U, Prosch H, Minkov M, Arico M, Braier J, et al.; DALHX- and LCH I and II Study Committee. Risk factors for diabetes insipidus in Langerhans cell histiocytosis. Pediatr Blood Cancer. 2006 Feb;46(2): 228-33.

15 Gatalica Z, Bilalovic N, Palazzo JP, Bender RP, Swensen J, Millis SZ, et al. Disseminated histiocytoses biomarkers beyond BRAFV600E: frequent expression of PD-L1. Oncotarget. 2015 Aug;6(23):19819-25.

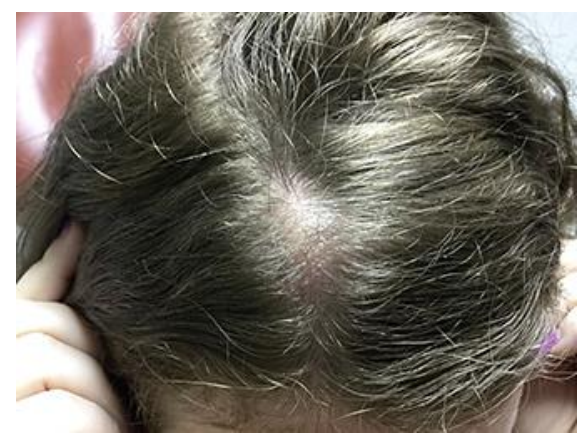

Fig. 1. Subcutaneous mass on the right frontal scalp.

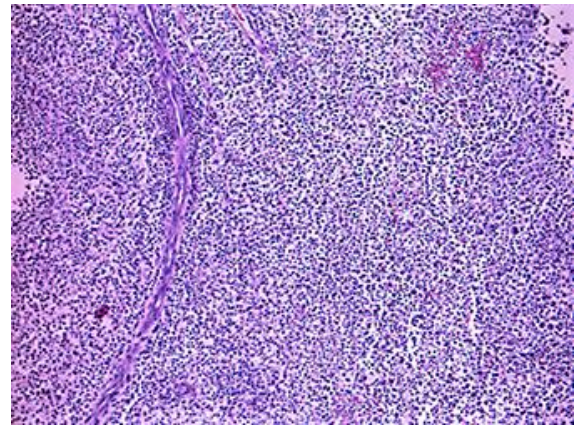

Fig. 2. A diffuse infiltrate of poorly cohesive cells was present.

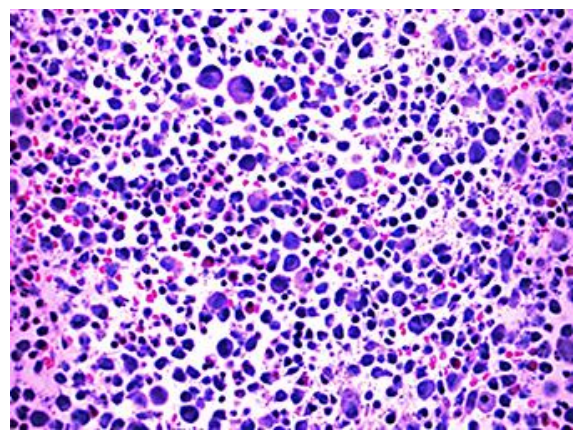

Fig. 3. Cells with reniform nuclei, some multinucleate, were present along with eosinophils.

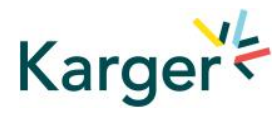




\section{Case Reports in Dermatology} www.karger.com/cde
ww

Foster et al.: Multifocal LCH with Intracranial Extension, Lymphadenopathy, and EBV Infection

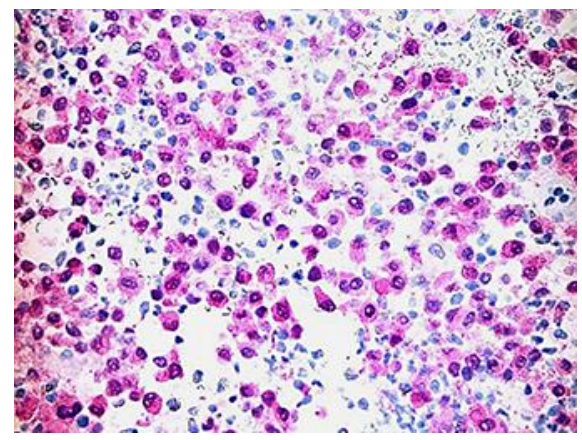

Fig. 4. Lesional cells stained with S100. They were also positive for CD207/langerin (not shown).

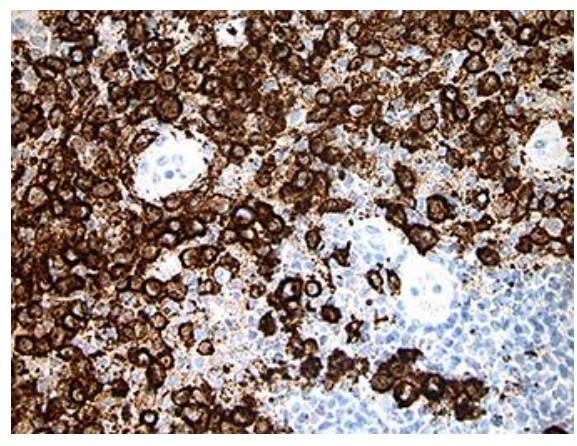

Fig. 5. Lesional cells stained with CD1a. They were also positive for CD207/langerin (not shown).

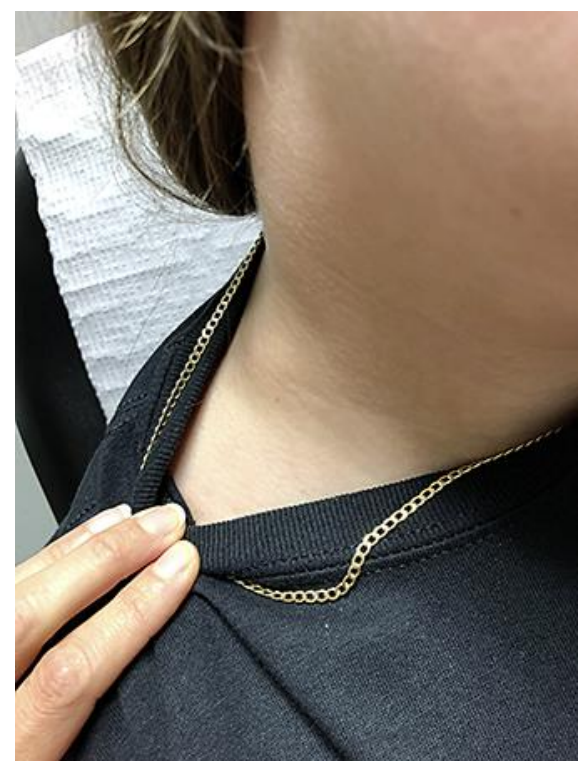

Fig. 6. Cervical lymphadenopathy in the right anterior neck.

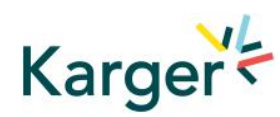


Case Reports in Dermatology
Case Rep Dermatol 2021;13:28-35

DOI: $10.1159 / 000511488$ (c) 2021 The Author(s).
www.karger.com/cde

Foster et al.: Multifocal LCH with Intracranial Extension, Lymphadenopathy, and EBV Infection

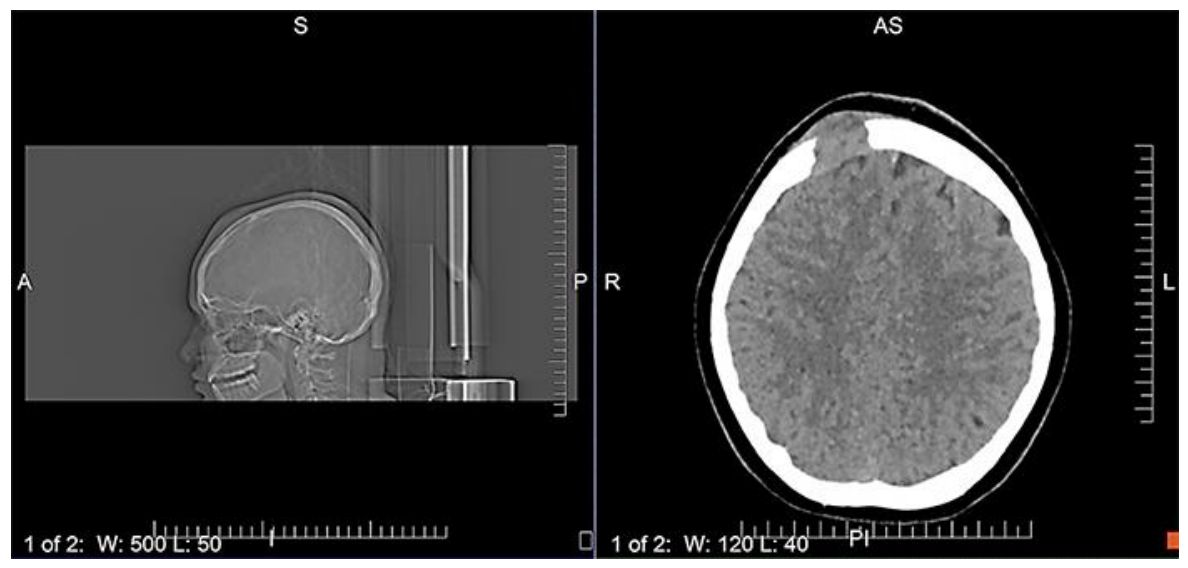

Fig. 7. CT scan of the head showing tumor extension from the scalp through the calvarium with extradural invasion. 